\title{
Configurações
}

Revista de sociologia

\section{Ana Mafalda Leite, Sheila Khan, Jessica Falconi, Kamila Krakowska (orgs.), Nação e Narrativa Pós- colonial II. Angola e Moçambique - Entrevistas. Lisboa: Edições Colibri, 2012}

\section{Elena Brugioni}

\author{
(2) OpenEdition \\ Journals \\ Edição electrónica \\ URL: http://journals.openedition.org/configuracoes/2188 \\ DOI: $10.4000 /$ configuracoes. 2188 \\ ISSN: 2182-7419 \\ Editora \\ Centro de Investigação em Ciências Sociais \\ Edição impressa \\ Data de publição: 1 Dezembro 2013 \\ Paginação: 233-234 \\ ISBN: 1646-5075 \\ ISSN: 1646-5075 \\ Refêrencia eletrónica \\ Elena Brugioni, « Ana Mafalda Leite, Sheila Khan, Jessica Falconi, Kamila Krakowska (orgs.), Nação e \\ Narrativa Pós-colonial II. Angola e Moçambique - Entrevistas. Lisboa: Edições Colibri, 2012 », \\ Configurações [Online], 12 | 2013, posto online no dia 08 outubro 2014, consultado o 19 abril 2019. \\ URL : http://journals.openedition.org/configuracoes/2188; DOI : 10.4000/configuracoes.2188
}

Este documento foi criado de forma automática no dia 19 Abril 2019.

(c) CICS 


\title{
Ana Mafalda Leite, Sheila Khan, Jessica Falconi, Kamila Krakowska (orgs.), Nação e Narrativa Pós- colonial II. Angola e Moçambique - Entrevistas. Lisboa: Edições Colibri, 2012
}

\author{
Elena Brugioni
}

1 Resultado do Projeto de Investigação Nação e Narrativa Pós-colonial do CESA (Centro de Estudos sobre África, Ásia e América Latina da Universidade de Lisboa), liderado por Ana Mafalda Leite e financiado pela Fundação para a Ciência e a Tecnologia (PTDC/ AFR/68941/2006), o volume recolhe doze entrevistas de escritores angolanos e moçambicanos, um conjunto de ensaios de autoria das organizadoras (Ana Mafalda Leite, Sheila Khan, Jessica Falconi e Kamila Krakowska) e um texto In Memoriam dedicado a Ruy Duarte de Carvalho de autoria de Livia Apa.

2 As entrevistas são conduzidas a partir dos tópicos do projeto - Nação e Narrativa Póscolonial - e contêm testemunhos e reflexões de algumas das vozes mais originais das chamadas Literaturas Africanas de língua portuguesa, apresentando um conjunto de questões, visões e pontos de partidas para refletir em torno das práticas narrativas e do paradigma crítico e epistemológico nacional. Para além disso, os ensaios que integram o livro e que se encontram na primeira parte, oferecem um enquadramento conceptual e epistemológico fundamental da prática da entrevista dentro da perspetiva disciplinar das Ciências Humanas e, mais especificamente, no âmbito crítico das Literaturas Angolana e Moçambicana e dos Estudos Pós-coloniais.

3 Os aspetos que tornam esta coletânea de entrevistas uma leitura de grande interesse, bem como um indispensável instrumento de trabalho e pesquisa, são multíplices e têm 
sobretudo a ver com algumas das questões que as organizadoras do livro salientam nos seus ensaios introdutórios.

Em primeiro lugar, citando o texto de Sheila Khan, sobressaem a importância e a necessidade das deslocalizações que pautam a realização das entrevistas, desempenhando simultaneamente um papel central, num plano epistemológico, e um papel conceptual, do ponto de vista da investigação no âmbito das Ciências Sociais e Humanas, e logo destacando a viagem e a subjetividade como imperativos fundamentais da investigação e do pensamento crítico.

Um segundo aspeto, a meu ver, fundamental é desenvolvido no ensaio de Jessica Falconi, cuja reflexão crítica e conceptual foca a questão do arquivo, na especificidade dos contextos de Angola e Moçambique. A partir de algumas das problemáticas que marcam o que vem sendo definido como archival turn, Falconi reflete em torno das práticas de construção de um arquivo nacional em contexto pós-colonial, destacando o campo cultural e literário como lugar seminal para repensar a relação entre história, memória e nação.

6 Finalmente, no ensaio de Kamila Krakowska, a problematização prende-se com um paradigma crítico e conceptual fundador tal como o do testemunho, propondo a autora uma interessante articulação entre ficção e realidade, narrativas e nação, e esboçando, deste modo, algumas das problemáticas que marcam a relação entre o ético e o estético.

Dentro do enquadramento crítico e conceptual proposto pelos ensaios introdutórios, as entrevistas de escritoras e escritores de Angola e Moçambique adquirem significados ulteriores, dando testemunho de reflexões críticas e criativas fundadoras para repensar alguns dos mais complexos desafios que marcam a contemporaneidade pós-colonial. É através das palavras de Luandino Vieira, Ana Paula Tavares, Boaventura Cardoso, José Eduardo Agualusa, Ondjaki, Pepetela, Ruy Duarte de Carvalho, João Paulo Borges Coelho, Marcelo Panguana, Mia Couto, Paulina Chiziane, Ungulani Ba Ka Khosa e Luís Carlos Patraquim, que nação e narrativa são postas em contraponto, oferecendo leituras e problematizações tão significativas quanto variadas e que constituem fontes indispensáveis em vista da construção de (outros) arquivos no espaço/tempo da póscolonialidade.

Num plano teórico mais alargado, o que surge pelos diálogos que pautam esta coletânea é uma constelação conceptual, onde as relações entre experiência e objetividade, história e memória, ficção e realidade são reconfiguradas, apontando para um conjunto de questões e problemáticas significativas para uma reflexão crítica e epistemológica no âmbito das Ciências Sociais e Humanas. O livro Nação e Narrativa Pós-colonial II. Angola e Moçambique Entrevistas contribui, deste modo, para aprofundar e consolidar os estudos sobre Angola e Moçambique nos contextos de língua portuguesa, proporcionando o surgir de um conhecimento mais amplo e situado de contextos sociais, políticos e culturais complexos e heterogéneos tais como os de Angola e Moçambique. 
AUTOR

\section{ELENA BRUGIONI}

Centro de Estudos Humanísticos - CEHUM, Universidade do Minho ebrugioni@ilch.uminho.pt 